This item was submitted to Loughborough's Research Repository by the author.

Items in Figshare are protected by copyright, with all rights reserved, unless otherwise indicated.

\title{
Cities in the making of world hegemonies
}

PLEASE CITE THE PUBLISHED VERSION

https://doi.org/10.4337/9781781001011.00009

PUBLISHER

(C) Edward Elgar

VERSION

AM (Accepted Manuscript)

LICENCE

CC BY-NC-ND 4.0

\section{REPOSITORY RECORD}

Taylor, Peter J., Michael Hoyler, and Dennis Smith. 2019. "Cities in the Making of World Hegemonies". figshare. https://hdl.handle.net/2134/9246. 
This item was submitted to Loughborough's Institutional Repository (https://dspace.lboro.ac.uk/) by the author and is made available under the following Creative Commons Licence conditions.

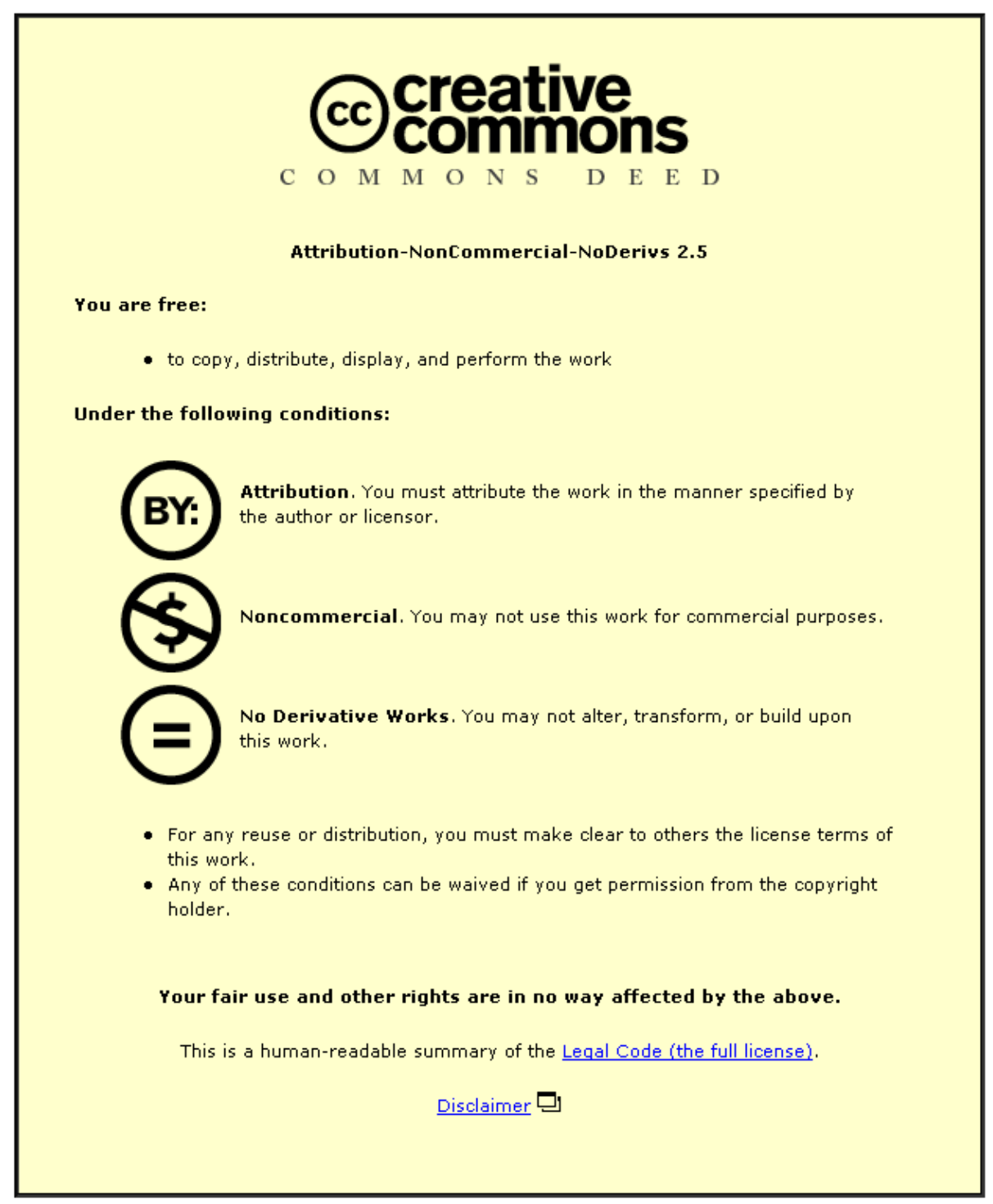

For the full text of this licence, please go to: http://creativecommons.org/licenses/by-nc-nd/2.5/ 


\section{Cities in the making of world hegemonies}

Peter J. Taylor, Michael Hoyler and Dennis Smith

\section{Introduction: Wallerstein's World Hegemonies}

In Immanuel Wallerstein’s (1979, 2004) world-systems analysis the modern world-system developed in the 'long sixteenth century' (c.1450-c.1650) as a European-Atlantic worldeconomy and expanded to become global in scope around 1900. This world-system was different from previous successful historical systems because of the enhanced importance of economic processes. Prior world-empires were political entities, the modern world-system developed as a political economy entity: the capitalist world-economy. It was able to achieve and maintain this political economy because of the fragmented nature of modern political structures. Earlier world-systems had a single over-arching political structure (one sovereignty); in the modern world-system there developed a competitive inter-state system (multiple sovereignties). And among the numerous states within the modern world-system, there were a few that were very special; Wallerstein (1984) calls them 'hegemonic states'.

Hegemonies constitute the prime time and space coordinates of the modern worldsystem. They are crucial to the on-going development and survival of the system over the halfmillennium of its existence. Wallerstein (1984) identifies just three cases: the Dutch (the United Provinces) in the late sixteenth and seventeenth centuries, the British (the United Kingdom) in the late eighteenth and nineteenth centuries, and the Americans (the United States) in the twentieth century. According to Wallerstein, the economic development dimension of hegemony consists of three stages of increasing economic dominance, first in production, followed by commercial prowess, and culminating in financial command. High hegemony, the peak of economic power, occurs when the hegemonic state is leading simultaneously in all three areas - production, commerce and finance. Economic dominance is lost in the same order: other 
countries 'catch up' first in production and then in commerce, leaving finance as the last vestige of hegemonic power. This rise and fall of hegemonic power is the hegemonic cycle, the prime 'rhythm' of the modern world-system.

But this hegemonic mega-process never went unchallenged. And this is where the political survival dimension of hegemony comes into play. At some time within each hegemonic cycle there has been a 'world war' in which the hegemonic state led an alliance to defeat a military imperial threat to the system. Thus the Dutch defeated the Habsburg threat in the Thirty Years War (1618-1648), the British defeated the French threat in the Revolutionary and Napoleonic Wars (1792-1815) and the USA defeated the German threat in the twentieth century World Wars (1914-45). These three are ‘world’ wars not just because of their size and scope, but crucially because they determined the future survival of the modern world-system. If any one of the counter-hegemonic threats had succeeded then the world-economy would have reverted to a new world-empire. Hence hegemonic states combine both economic and political powers to develop and reproduce the modern world-system.

\section{Bringing Cities into the Argument}

Cities hardly feature at all in this story of the modern world-system. And since one of the unique features of modernity is ever-increasing urbanization far in excess of any previous world-system, this should make us cautious in considering Wallerstein's otherwise groundbreaking account of how modernity came to be. His only important mention of cities is in relation to finance: the hegemonic state's financial prowess is concentrated in a single city: first Amsterdam, then London and finally New York. It is in these primate international financial centres that a remnant of hegemony survives long past their state's dominance. This part of Wallerstein’s story derives from an earlier treatment of early-modern Europe by Fernand Braudel (1984). He identifies ‘world-cities’ as financial control centres from the fifteenth century starting with Venice, Antwerp and Genoa before advancing to Amsterdam, London and 
New York. He interprets Amsterdam as the transition case from early-modern to modern finance: it is a 'half-way house' between initial city control to later state control of international finance. In other words London's and New York's financial statuses, and to a lesser extent Amsterdam's, are premised on their location within a hegemonic state. Wallerstein diverges from Braudel only in firmly fixing Amsterdam's financial prowess to its state’s hegemony.

Braudel brings cities into the argument but in a very limited way. His treatment of cities emphasizes their hierarchical nature with particular emphasis on the apex of the hierarchy. Thus although empirical examples in his work show much evidence of city networks, he is not a source for approaching cities in the modern world-system through their networking processes. Here we will use the generic theories of Jane Jacobs $(1969,1984)$ that link dynamic cities to economic development. In her account cities come in groups that need each other to prosper; these are city networks. She defines cities by a process that generates new work through interaction between cities, which in turn creates increasingly complex divisions of labour in city economies. When this process operates successfully it produces explosive city growths, which is how she argues that economic development happens. It follows therefore that since the modern world-system is the most successful historical system in terms of economic development, it must be because it consists of more dynamic cities than other historical systems. Thus unique levels of urbanization are not a consequence of the rise and reproduction of the modern world-system, they are its cause. And so we come to the proposition on which this chapter is based: cities must be central players in the three hegemonic cycles; in the rise of the high hegemony, dynamic cities should be to the fore, in the decline phase their influence should wane.

\section{A Project to Test the Theory}

That's the theory, how does the empirical evidence stack up? This question has been answered in a large survey of cities in the modern world-system from 1500 to the present (Taylor et al., 
2010) and the results are summarized below. Of course, it is impossible to get comprehensive data on city economies for the length of the modern world-system but there are reasonable population estimates of cities available for our period. Historically, economic growth and population growth have changed in tandem: dynamic cities that create much new work attract more migrants than less dynamic cities with fewer jobs on offer. Thus we can use demographic change as a surrogate for economic change. Defining different rosters for each century (cities qualified with populations of 10 per cent or more of the average population of the three most populous cities in each century), population changes were computed for 50-year intervals from 1500. Explosive city growths were then defined as cities with an average annual population increase of 1 per cent over a 50-year period. This method was only used for periods up to 1950 because at this point, in the second half of the twentieth century, the simple relation between demographic and economic change broke down (the massive de-peasantization of poorer countries has produced very large mega-cities in which population growth far out-paced economic growth in terms of (formal) jobs). Thus a search for a different surrogate was undertaken. The most suitable was found to be the change in airline connections per city and these were analysed as above from 1970 to 2005: cities that expanded their connections at an annual rate of 1 per cent or over were deemed to have experienced an explosive city growth.

\section{Explosive City Growths in Hegemonic Cycles}

From this exercise 184 explosive city growths were identified. They were strictly limited by the bounds of the modern world-system: from 1500 to 1750 only European and American cities were included; Ottoman, Russian and Indian cities were added from 1750; and Chinese and Japanese cities were included from 1850. Our interest is in the changing importance of Dutch, British and US cities within this population of 184 explosive city growths. The results will be shown and discussed for three periods: 1500 to 1700 for investigating Dutch hegemony; 1700 to 1900 for investigating British hegemony, and 1800 to 2005 for investigating US hegemony. 
Note the overlap in the last two periods. It is unusual to consider US hegemony as early as 1800 but our analysis does lead us back this far: the implications of this will be discussed later.

1500-1700: Holland's Cities and Dutch Hegemony

Dutch cities with economic spurts are highlighted for the period 1500 to 1700 in Table 3.1. This early-modern period shows relatively few economic spurts and they are concentrated in the sixteenth century. The 'crisis of the seventeenth century' is clearly reflected in these results, with only two economic spurts in the second half of the seventeenth century.

[TABLE 3.1]

Although only four Dutch cities are featured, they experienced eight examples of explosive city growth between them. Led by Amsterdam with three such spurts, the table confirms that the Dutch Republic was not simply 'Amsterdam’s city-state’, as has been suggested Barbour, 1963), but was a multi-nodal city-region of several vibrant cities (Taylor, 2005). The most intriguing feature of the sequencing of these spurts is that they are evenly divided between the two centuries despite the fact that the Dutch Republic only comes into being in the last 20 years of the fifteenth century and its hegemonic cycle is usually deemed to begin in 1598 at the earliest. Thus we find Amsterdam's first explosive city growth well before the creation of the Dutch Republic, and there are three explosive city growths that build up Dutch hegemony (Amsterdam, Haarlem and Leiden) before hegemony begins. In the seventeenth century there is the reverse pattern with three economic spurts (Amsterdam, Leiden and Rotterdam) during the period covering high hegemony (1609-1648); but with only the latter city continuing with a final Dutch city spurt in the downside of the cycle. 
During this period the Dutch went largely without a serious economic rival; France came the closest with five cities (Rouen, Bordeaux, Paris, Lyon and Marseilles) and six spurts, but all are consistently smaller than the Dutch city growths.

There are three key points to make from these results:

1. High hegemony is represented by a higher proportion of economic spurts in the modern world-system (three out of eight or 32.5 per cent, discounting 1650-1700 when there were only two spurts). In other words economic spurts correlate with high hegemony.

2. There is a definite front-loading of economic spurts to such a degree that half occur before hegemony itself. In other words half of all Dutch spurts come before hegemony, which is entirely consistent with cities creating the hegemony.

3. All the cities involved are from one of the seven provinces that constituted the Dutch Republic: Holland. In other words, the creation and reproduction of Dutch hegemony is not state-wide: only Holland was hegemony-making in the period 1500 to 1700.

1700-1900: Northern British Cities and British Hegemony

British cities with economic spurts are highlighted for the period 1700 to 1900 in Table 3.2. The number of spurts remains low in the eighteenth century but there is a rapid expansion in the nineteenth century reflecting the spread of industrialization that is, of course, British hegemony's chief contribution to the modern world-system.

[TABLE 3.2]

In this period 7 British cities are featured with 21 explosive city growths between them. The key feature is the dominance of the four great cities of northern Britain: Birmingham, Glasgow, Liverpool and Manchester. These four cities dominate the eighteenth century with 8 out of the 13 economic spurts recorded in the modern world-system. These big four cities 
continue with explosive growth in both nineteenth century periods, although gradually falling down the ranks. Their clustered position just below four US cities in 1800-1850 reflects the fact that the US cities were starting from a lower population base; that is to say, Liverpool, Manchester, Birmingham and Glasgow still dominated the world-economy. In both nineteenth century lists they are joined by Newcastle and London. London was conspicuous by its absence among eighteenth century city spurts and, although featuring in the nineteenth century, its economic spurts are lowly ranked. Newcastle is somewhat like Rotterdam in the Dutch cycle: it arrives late and has its largest spurt at the end of the hegemonic cycle.

It is noteworthy that although France is Britain's main rival during its hegemony its economic competition was severely weak: in Table 3.2 only two French cities are featured, Paris and Lyon, both with lowly ranked spurts in the nineteenth century. Clearly the French were less of an economic rival to the British than they were to the Dutch in the previous cycle.

There are three key points to make from these results:

1. High hegemony (mid nineteenth century) is represented by a higher quantity of economic spurts in the modern world-system (although proportions are lower given the large differences in totals between the two centuries). In other words, the greatest number of British economic spurts correlate with high hegemony.

2. There is a very strong front-loading of economic spurts to such a degree that the four leading northern cities account for well over half the economic spurts in the eighteenth century (8 out of 13 or 61.5 per cent). This shows that multiple spurts come before hegemony, which is entirely consistent with cities creating the hegemony.

3. The four key cities in northern British cities are consistently found in all four periods and are in the top eight ranks for the first three periods. They are joined by another northern city with two spurts in the nineteenth century: Newcastle. London's economic spurts appear in the nineteenth century but, with one exception, are ranked below the northern cities. In other words, the creation and reproduction of British hegemony is 
not state-wide; it is largely the work of the great northern British cities and it is here that we find hegemony-making in the period 1700 to 1900.

1800-2005: Manufacturing Belt (plus California and Texas) Cities and American Hegemony

US cities with economic spurts are highlighted for the period from 1800 to 2005 in Table 3.3. There is never any discussion in the literature of the US hegemonic cycle going back as far as 1800 but our results strongly suggest that this is where to start.

[TABLE 3.3]

In this period 15 US cities are featured with 25 explosive city growths between them. This confirms a trend of absolute increases in number of economic spurts in cities of hegemonic states but with trend of relative decline in the proportion of such economic spurts within the modern world-system. The surprise is the top four rankings in 1800-1850 for the leading east coast cities: New York, Baltimore, Philadelphia and Boston. These cities continue to feature in the second half of the nineteenth century, albeit with much lower rankings, but now Chicago is ranked first and Pittsburgh fourth, showing important inland explosive city growths. US dominance of spurts is greatest in the first half of the twentieth century, with four of the top five places: explosive city growth has now reached the Pacific coast with Los Angeles ranked first, two Texas cities ranked second and third (Houston and Dallas), and with another inland industrial centre, Detroit, ranked fifth. In addition, San Francisco and Seattle add to the Pacific coast representation and Atlanta to southern representation. Washington also features for the first time and New York, Boston and Philadelphia, but not Baltimore, continue with economic spurts in the new century. In the 1970-2005 period, the US returns to having just four cities in the list. Now it is Washington with the highest ranking (third), Los Angeles and Chicago continue to feature, and Miami makes a first appearance. Although the change of criteria makes 
comparisons with the final column in Table 3.3 problematic, nevertheless the result indicating relatively fewer economic spurt cities towards the end of the hegemonic cycle is consistent with previous results (Tables 3.1 and 3.2).

In this hegemonic cycle the main rival is very clear: Germany has 7 cities with 16 episodes of explosive city growth. Their main challenge was in the second half of the nineteenth century, when there were 5 German cities near the top of the economic spurts: Leipzig (ranked 3rd), Berlin (6th), Dresden (8th), Hamburg (11th) and Munich (14th). Unlike the French in the British cycle, Germany was a very credible economic rival to the USA during its cycle.

There are three key points to make from these results:

1. The highest quantity of economic spurts in the modern world-system, featuring 11 US cities, occurs as high hegemony is being reached (1950). In other words, economic spurts correlate with the coming of high hegemony.

2. There is a very unexpected, very early, front-loading of economic spurts featuring east coast cities. This means that spurts come well before hegemony, which is entirely consistent with cities creating the hegemony.

3. The key cities are largely from what was generally referred to as the 'manufacturing belt' (east coast plus mid-west cities) with important outliers in California and Texas. In other words, the creation and reproduction of US hegemony is not state-wide: only select parts of the USA can be considered hegemony-making in the period 1800-2005.

\section{Conclusions}

From this evidence, it is very clear that the geography of explosive economic growths in the modern world-system is related to the development and reproduction of world hegemonies. Further, the timing of the city spurts is additionally informative. Peaks of Dutch, British and American city spurts are found at the centre of their respective hegemonic cycles approximating their high hegemonies. But the two key results are to be found in the distribution of these city 
spurts across each of the three time periods and within their respective states. If vibrant cities were merely the result of state hegemonic processes then we might expect them to be relatively evenly spread across different periods of the cycle and across the territory of the state. This is not the case in any of the three world hegemonies. Rather there are two consistent patterns. First, in terms of timing, dynamic cities and their economic spurts are front-loaded in the cycle. This indicates that the cities are hegemony-makers and that portends of hegemony can be found much earlier than Wallerstein's initial framing of hegemonic cycles allows for. Secondly, the dynamic cities are concentrated in just part of the state's territory. This indicates that the hegemony-making occurs in specific vibrant economic regions.

For reasons of resource and manageability, the research exercise upon which this chapter is based has only searched out explosive city growths in the more important cities within the modern world-system. But for the vibrant economic regions of the hegemonic states this is only the tip of the urban-economic dynamism. For instance, each of the following pairs of cities prospered during their relevant hegemonic cycles: in Holland Dordrecht and Hoorn, in Britain Bradford and Preston, and in the US manufacturing belt Cleveland and Buffalo. Quite clearly, hegemonies were created through dense networks of thriving cities generating economic development in three economic core regions of the hegemonic states. Hence this conclusion: it is these cities generating myriad new work through their networking that create and reproduce hegemony, not territorial states.

One final point concerning hegemonic states and their territories: this chapter’s conclusion is eminently sensible given basic knowledge of the geography of hegemonic state territories in their rise to high hegemony. In the seventeenth century Dutch Republic the outer provinces were economically backward with little or no city dynamism (Taylor, 1994); the nineteenth century United Kingdom included Ireland, which suffered famine causing a mass exodus that indicates a dearth of city dynamism; and in the USA in the twentieth century as far as the 1960s, the ‘American South’ was another byword for economic backwardness, again indicating little or no city dynamism. And yet the states should not be entirely written out of the 
story. The dense creative city networks were initially concentrated within a single state; successful diffusion of new economic practices to cities in other states came later. This may be related to the relative economic liberalisms within the hegemonic states. Movement infrastructures are also important for maintaining economic dynamism and their geographical scale and capital expense often require state power and resources. From Dutch canals to British railways to the US inter-state road system, hegemonic states have enabled huge territorial infrastructures to be built by various means, including sponsoring, subsidizing or even building. But ultimately the hegemonic states' key contribution to hegemony has been, as Wallerstein (1984) originally argued, to ensure the survival of the system.

\section{Acknowledgements}

We acknowledge the support of the Leverhulme Trust for funding the research project of which this chapter is a part.

\section{References}

Barbour, V. (1963), Capitalism in Amsterdam in the Seventeenth Century, Ann Arbor, MI: University of Michigan Press.

Braudel, F. (1984), Perspective of the World, London: Collins. Jacobs, J. (1969), The Economy of Cities, New York: Random House.

Jacobs, J. (1984), Cities and the Wealth of Nations, New York: Random House.

Taylor, P.J. (1994), 'Ten years that shook the world: the United Provinces as the first hegemonic state’, Sociological Perspectives, 37 (1), 25-46.

Taylor, P.J. (2005), ‘Dutch hegemony and contemporary globalization', in J. Friedman and C. Chase-Dunn (eds), Hegemonic Declines: Present and Past, Boulder, CO: Paradigm Publishers, pp. 117-134. 
Taylor, P.J., A. Firth, M. Hoyler and D. Smith (2010), ‘Explosive city growth in the modern world-system: an initial inventory derived from urban demographic changes’, Urban Geography, 31 (7), 865-884.

Wallerstein, I. (1979), The Capitalist World-Economy, Cambridge: Cambridge University Press. Wallerstein, I. (1984), Politics of the World-Economy, Cambridge: Cambridge University Press. Wallerstein, I. (2004), World-Systems Analysis: An Introduction, Durham, NC: Duke University Press. 
Table 3.1 Dutch cities in the Dutch hegemonic cycle

\begin{tabular}{llll}
\hline \multicolumn{1}{c}{\begin{tabular}{c}
$1500-1550$ \\
\multicolumn{1}{c}{$(\mathrm{n}=12)$}
\end{tabular}} & \multicolumn{1}{c}{$(\mathrm{n}=11)$} & \multicolumn{1}{c}{$(\mathrm{n}=8)$} & $(\mathrm{n}=2)$ \\
\hline Lisbon & London & AMSTERDAM & Seville \\
Seville & AMSTERDAM & LEIDEN & ROTTERDAM \\
Augsburg & HAARLEM & ROTTERDAM & \\
Antwerp & LEIDEN & London & \\
Magdeburg & Bordeaux & Paris & \\
AMSTERDAM & Cuenca & Lyon & \\
Hamburg & Vicenza & Hamburg & \\
London & Milan & Marseilles & \\
Lecce & Torino & \\
Rouen & Paris & \\
Venice & Jerez & \\
Catania & & \\
\hline
\end{tabular}

Note: $\mathrm{n}=$ number of economic spurts.

Source: derived from Taylor et al. (2010) 
Table 3.2 British cities in the British hegemonic cycle

\begin{tabular}{|c|c|c|c|}
\hline $1700-1750$ & $1750-1800$ & $1800-1850$ & 1850-1900 \\
\hline$(n=7)$ & $(n=6)$ & $(\mathrm{n}=25)$ & $(\mathrm{n}=39)$ \\
\hline LIVERPOOL & MANCHESTER & New York & Chicago \\
\hline BIRMINGHAM & LIVERPOOL & Baltimore & Buenos Aires \\
\hline Cadiz & GLASGOW & Philadelphia & Leipzig \\
\hline Cork & BIRMINGHAM & Boston & Pittsburgh \\
\hline MANCHESTER & Barcelona & LIVERPOOL & New York \\
\hline GLASGOW & Moscow & MANCHESTER & Berlin \\
\hline \multirow[t]{12}{*}{ BRISTOL } & & BIRMINGHAM & NEWCASTLE \\
\hline & & GLASGOW & Dresden \\
\hline & & Bombay & Boston \\
\hline & & Rio de Janeiro & Budapest \\
\hline & & Brussels & Hamburg \\
\hline & & NEWCASTLE & Rio de Janeiro \\
\hline & & Plus & Plus \\
\hline & & LONDON (15) & BIRMINGHAM (15) \\
\hline & & & MANCHESTER (19) \\
\hline & & & GLASGOW (27) \\
\hline & & & LONDON (29) \\
\hline & & & LIVERPOOL (37) \\
\hline
\end{tabular}

Note: $\mathrm{n}$ = number of economic spurts; figures in brackets indicate rank of British cities below the top 12.

Source: derived from Taylor et al. (2010) 
Table 3.3 American cities in the American hegemonic cycle

\begin{tabular}{|c|c|c|c|}
\hline $1800-1850$ & $1850-1900$ & $1900-1950$ & $1970-2005 *$ \\
\hline$(n=25)$ & $(n=39)$ & $(n=39)$ & $(\mathrm{n}=35)$ \\
\hline NEW YORK & CHICAGO & LOS ANGELES & Beijing \\
\hline BALTIMORE & Buenos Aires & HOUSTON & Shanghai \\
\hline PHILADELPHIA & Leipzig & DALLAS & WASHINGTON \\
\hline BOSTON & PITTSBURGH & Hong Kong & Osaka \\
\hline Liverpool & NEW YORK & DETROIT & Seoul \\
\hline Manchester & Berlin & São Paulo & Singapore \\
\hline Birmingham & Newcastle & Shanghai & Budapest \\
\hline Glasgow & Dresden & Seoul & Madrid \\
\hline Bombay & BOSTON & SEATTLE & Vienna \\
\hline Rio de Janeiro & Budapest & Buenos Aires & Berlin \\
\hline Brussels & Hamburg & ATLANTA & Tokyo \\
\hline \multirow[t]{8}{*}{ Newcastle } & Rio de Janeiro & Toronto & Hamburg \\
\hline & Plus & Plus & Plus \\
\hline & PHILADELPHIA (22) & WASHINGTON (14) & LOS ANGELES (15) \\
\hline & BALTIMORE (25) & SAN FRANCISCO & MIAMI (20) \\
\hline & & (16) & CHICAGO (28) \\
\hline & & NEW YORK (24) & \\
\hline & & BOSTON (32) & \\
\hline & & PHILADELPHIA (33) & \\
\hline
\end{tabular}

Note: $\mathrm{n}$ = number of economic spurts; figures in brackets indicate rank of cities below the top 12.

* the results for this column relate to spurts on scheduled airline flights

Source: derived from Taylor et al. (2010) 